\title{
JOURNAL.RU
}

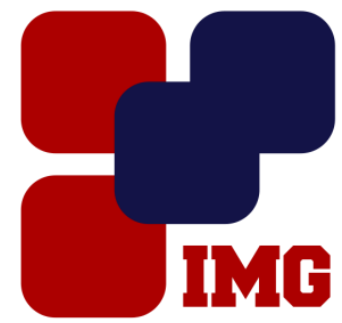
IVANOY Management GROUP

Николаева К.В., Стороженко И.И., Федорин С.В.

Военно-медиџинская академия им.С.М. Кирова Санкт-Петербург, Россия

doi: $10.18411 / 1 \mathrm{j}-30-06-2017-46$

idsp 000001:1j-30-06-2017-46

\section{Развитие и совершенствование выносливости у курсантов военно- медицинского вуза с применением тренажерных средств}

\section{Аннотация}

Специализация медицинского направления относится к типу «человек человек» и требует от обучаемых интеллектуальных, физических, нервнопсихических затрат, в том числе определенных профессионально важных качеств. Труд медицинских специалистов связан с большой ответственностью. Некоторые профессионально важные качества можно развить и повысить с помощью определенного тренировочного процесса на занятиях физической культурой.

Ключевые слова: физические качества, развитие выносливости, профессионально важные качества врача, устойчивость к утомлению, выносливость к эмоциональным и физическим нагрузкам, использование тренажерных средств.

\section{Abstract}

Specialization in the medical field is of type «man-man» and requires of the learners intellectual, physical, psychical costs, including certain professionally important qualities. The work of health care professionals is a big responsibility. Some professionally important qualities we can develop and improve through specific training process on physical education.

Keywords: physical quality, training of cadets medical, endurance training, professionally important qualities of the doctor, resistance to fatigue, endurance to emotional and physical stress, use of training AIDS.

Последние десятилетия научно-технический прогресс оказывает значительное влияние на общество в целом и на работающее население в 
частности. Число лиц, выполняющих в основном умственную работу (труд с преимущественным напряжением мыслительных процессов, управленческий труд, операторский труд, труд с высоким нервным напряжением, труд медицинских работников, в том числе и труд учащихся) увеличивается, в то время как число людей, занятых тяжелым физическим трудом, снижается.

Кроме регулярного нервно-психического напряжения к специфическим профессиональным факторам умственного труда следует отнести и гипокинезию, влияние которой на состояние организма невозможно переоценить. Использование технических средств, робототехники и других результатов современных открытий в жизнедеятельности человека влечет за собой снижение активности организма и наименьшее использование его биологических ресурсов, а объем информации в результате увеличения темпа работы, сферы общения с людьми и сферы обслуживания стремительно растет.

В настоящее время медицинская сфера не осталась нетронутой: развитие промышленной техники, автоматизация производства, внедрение автоматических систем управления меняют и характер производительного труда, что в свою очередь ведет к повышению специальных требований, предъявляемых к организму человека и к физической подготовленности будущего врача. То есть в основе физической подготовки курсантов-медиков к предстоящей трудовой деятельности - всестороннее физическое развитие. Это основа для совершенствования всех жизненно важных функций организма.

Так как особенности медицинского труда могут отрицательно влиять не только на состояние здоровья и снижать общую выносливость, то наиболее эффективным средством развития и совершенствования выносливости у будущих специалистов является приобщение их к физической культуре и спорту с учетом особенностей профессиональной деятельности - профессиональной прикладной физической подготовки с использованием тренажерных средств.

В результате контрольных проверок физической подготовленности курсантов выявлен недостаточно высокий уровень развития общей выносливости, а это физическое качество является наиболее важным для будущего специалиста медицинского профиля. Соответственно, профессионально важные качества для них необходимо развивать средствами и методами физической культуры в той степени, которая позволит им на самом высоком уровне выполнять обязанности по предназначению, что и легло в основу разработки данной методики. 
Целью нашего исследования является теоретическое обоснование и разработка для курсантов-медиков экспериментальной методики по физической подготовке на основе развития и совершенствования выносливости с применением тренажерных средств.

В результате анализа профессиональной деятельности специалистов медицинского профиля и литературы, нами использованы различные средства и методы физической подготовки для развития профессионально важных качеств курсантов-медиков, в т. ч. и с применением тренажерных средств, однако работ, направленных на развитие и совершенствование выносливости у курсантовмедиков с применением тренажерных средств не обнаружено.

На основе полученных результатов разработан и экспериментально апробирован специальный комплекс упражнений, направленный на развитие и совершенствование выносливости у курсантов военно-медицинского вуза.

Период обучения курсантов совпадает с активным формированием духовных и физических качеств, с подготовкой к выполнению профессиональных функций. Проблема формирования двигательной активности будущих специалистов медицинской сферы имеет важное значение, поскольку с возрастом у человека все в большей степени проявляется гиподинамия, в т. ч. и у курсантов-медиков. Это обусловлено не только большим объемом аудиторных занятий, но и занятий, которые отводятся на самостоятельную работу, что, в свою очередь, способствует увеличению числа лиц с неудовлетворительным состоянием здоровья, предрасположенностью к частым заболеваниям, а значит недостаточно высоким уровнем развития физических качеств, особенно выносливости.

Физическое качество «Выносливость» определяют как важнейшее качество, которое проявляется и в профессиональной, и в спортивной, и даже в повседневной жизни людей регулярно и влияет на эффективное выполнение определенной деятельности за определенный интервал времени. Другими словами - это способность организма поддерживать необходимую для обеспечения профессиональной деятельности мощность нагрузки и противостоять утомлению, возникающему в процессе выполнения определенной работы.

Исходя из этого, в медицинской сфере чаще необходима специальная выносливость, например, статическая. Она связана с длительным нахождением тела в определенном положении в условиях сниженной подвижности, в т.ч. и в ограниченном пространстве. Необходима и специальная выносливость к 
продолжительной работе умеренной и малой мощности; к длительной работе переменной мощности и сенсорная выносливость. Последняя означает способность быстро и точно реагировать на внешние воздействия без снижения эффективности профессиональных действий, даже при условии утомления сенсорных систем. Сенсорная выносливость зависит от функционирования анализаторов, прежде всего: двигательного, зрительного, слухового, тактильного, вестибулярного.

В ходе систематических занятий физической культурой происходит адаптация организма к физическим нагрузкам, развитие физических качеств, в частности, общей выносливости, что, в свою очередь, способствует повышению умственной и физической работоспособности, которая является наиболее значимой для специалистов медицинской сферы. При развивающемся утомлении, либо в экстремальной ситуации или в условиях неблагоприятных воздействий внешней среды специалистам медицинского профиля особенно важно сохранять способность действовать с применением специальных навыков труда.

С целью увеличения времени работы с высокой эффективностью до появления признаков утомления был разработан специальный комплекс физических упражнений с использованием тренажерных средств, применение которого в период обучения курсантов-медиков позволяет сократить время адаптации организма к нагрузкам и одновременно с этим включает опережающее развитие и совершенствование уровня выносливости.

С использованием комплекса физических упражнений достигается повышение уровня устойчивости организма к неблагоприятным воздействиям внешней среды, а при регулярном использовании тренажерных средств, особенно в холодное время, достигается более высокий уровень физической подготовленности курсантов-медиков к предстоящим нагрузкам по предназначению. Это направление профессионально-прикладной физической подготовки повышает устойчивость организма курсантов-медиков и неблагоприятным факторам окружающей среды, тем самым, отвечая предъявляемым специфическим требованиям избранной специализации.

В результате проведенного исследования определены выводы, которые подтверждают выдвинутую нами рабочую гипотезу исследования, в т.ч.:

1. Анализ специфики профессиональной деятельности специалистов медицинского профиля показал, что в настоящее время подготовка специалистов-медиков проводится в недостаточно полном объеме, в частности, 
без учета профессионально прикладной физической подготовки для этих специальностей. Используемые средства, методы и формы физической подготовки для развития профессионально важных качеств курсантов-медиков нуждаются в дополнениях, в т.ч. и со стороны разработанного специального комплекса физических упражнений с применением тренажерных средств.

2. Установлено, что специальный комплекс физических упражнений не требует дополнительной материальной базы по физической подготовке, а использует уже имеющиеся тренажерные средства, что повышает экономический эффект процесса обучения курсантов академии.

$* * *$

1. Источник №1. Захаров Е.Н., Карасев А.В., Сафонов А.А. Энциклопедия физической подготовки (Методические основы развития физических качеств) / Под общей ред. А.В. Карасева. - М.: Лептос, 1994. - 368 с.

2. Источник №2. Лавриненко В.В. Развитие общей выносливости в короткие сроки для повышения профессиональной работоспособности курсантов окружных учебных центров. СПб. 2005. - 24 с.

3. Источник №3. Марищук В.Л. Психолого-педагогические аспекты физической подготовки. - Л.: ВДКИФК, 1985. - 5-10 с.

4. Источник №4. Навакатикян А.О., Крыжановская В.В. Возрастная работоспособность лиц умственного труда. Киев, 1979. - 208 с.

5. Источник№5. ТрековА.И. Методика совершенствования работоспособности курсантов вузов как средство повышения их военно- профессиональной готовности. / Дис. канд. пед. наук. Пермь. 2000. - 24 с. 